\title{
Croatian Registry of Patients with deep vein thrombosis - single centre data update
}

\section{Mislav Puljević*, Zoran Miovski, Majda Vrkić Kirhmajer, Krešimir Putarek, Ljiljana Banfić}

University of Zagreb School of Medicine, University Hospital Centre Zagreb, Zagreb, Croatia
KEYWORDS: deep vein thrombosis, registry, Croatia.

CITATION: Cardiol Croat. 2017;12(9-10):383. | https://doi.org/10.15836/ccar2017.383

*ADDRESS FOR CORRESPONDENCE: Mislav Puljević, Klinički bolnički centar Zagreb, Kišpatićeva 12, HR-10000 Zagreb, Croatia. / Phone: +385-91-4680-414 / E-mail: puljevicmislav@gmail.com

ORCID: Mislav Puljević http://orcid.org/0000-0003-1477-2581 • Zoran Miovski http://orcid.org/0000-0002-3850-8905 Majda Vrkić Kirhmajer http://orcid.org/0000-0002-1340-1917 • Krešimir Putarek http://orcid.org/0000-0003-0361-5740 Ljiljana Banfić http://orcid.org/0000-0002-4538-8980

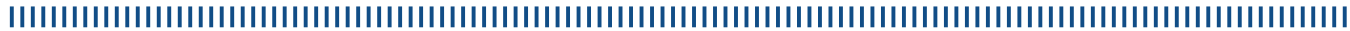

The knowledge about the actual prevalence of the disease is only partially possible because it applies only to patients treated in hospital. We do not have epidemiologically relevant data about venous thrombosis prevalence in Croatia. The Working Group on Angiology and Peripheral Vascular Diseases of the Croatian Cardiac Society has an initiative for formation of a national registry in order to obtain an epidemiological data of population morbidity, mode of treatment and prevention of venous thrombosis. ${ }^{1}$ We will present the results of a prospective epidemiological study in the University Hospital Centre Zagreb, which should represent a pilot study that could be a model for the formation of a national Registry "Venous Thrombosis". Questionnaire includes the relevant data relating to the etiology of deep vein thrombosis, scope and localization of the disease, complications of disease, mode of mandatory and long-term treatment, as well as possible complications during treatment. Results of one center collected in period of 20 months during 2016 and 2017, included a total of only 142 patients. The data correspond to the world literature published so far.
RECEIVED:

September 24, 2017

ACCEPTED:

September 26, 2017

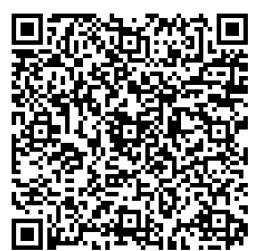

LITERATURE IIIIIIIIIIIIIIIIIIIIIIIIIIIIIIIIIIIIIIIIIIIIIIIIIIIIIIIIIIIIIIIIIIIIIIIIIIIIIIIIIIIIIIIIIIIIIIIIIIIII

1. Banfić Lj. [Guidelines on diagnosis, treatment and prevention of venous thrombosis]. Cardiol Croat. 2016;119):351-374. Croatian. https://doi.org/10.15836/ccar2016.351 